ISSN 2087-3336 (Print) | 2721-4729 (Online)

TEKNOSAINS: Jurnal Sains, Teknologi dan Informatika

Volume 9, Nomor 1, Januari 2022, hlm. 47-54

http://jurnal.sttmcileungsi.ac.id/index.php/tekno

DOI: 10.37373

\title{
Pemanfaatan Bahan Alam Anchor sebagai Bahan Konservasi Fosil di Sangiran
}

\section{Utilization of Anchor Natural Materials as Fossil Conservation Materials in Sangiran}

\author{
Nurul Fadlilah $^{1 *, 2}$, Kun Harismah ${ }^{1}$ \\ ${ }^{1 *, 2}$ Departement of Chemichal Engineering, Universitas Muhammadiyah Surakarta, Indonesia \\ ${ }^{2}$ Balai Pelestarian Situs Manusia Purba Sangiran \\ ${ }^{1 *, 2}$ J1. A. Yani, Mendungan, Pabelan, Kec. Kartasura, Kabupaten Sukoharjo, Jawa Tengah 57169 \\ 1* Jl.Sangiran Km 4, Krikilan, Kalijambe, Sragen Regency, Central Java 57275 \\ *Koresponden Email:d500191017@student.ums.ac.id; kun.harismah@ums.ac.id,
}

Artikel dikirim: 10/11/2021

Artikel direvisi: 23/11/2021

Artikel diterima: 09/12/2021

\begin{abstract}
ABSTRAK
Balai Pelestarian Situs Manusia Purba Sangiran telah menggunakan bahan alam anchor sebagai bahan perekat untuk menyambungkan fosil yang patah sejak tahun 2018 setelah melakukan penelitian selama dua tahun yaitu pada tahun 2016 dan pada tahun 2017. Seiring berjalannya waktu penggunaan bahan alam anchor mengalami kerusakan seperti hasil sambungan patah atau retak yang diakibatkan penyimpanan fosil yang kurang tepat. Penelitian ini bertujuan untuk menentukan kekuatan mekanik campuran fosil dan anchor. Penelitian menggunakan rancangan acak lengkap satu faktor dengan variasi perbandingan fosil ukuran 100 mesh dan anchor (1:1, 2:1, dan 3:1) dengan dua ulangan. Kemudian melakukan pengujian kuat tekan menggunakan universal testing machine berdasarkan standar ASTM D695-96. Hasilnya menunjukkan nilai kuat tekan tertinggi campuran serbuk fosil dan anchor dengan pada perbandingan 1:1 yaitu 19,996 N/mm² dan nilai kuat tekan terendah pada perbandingan serbuk fosil dan anchor 3:1 yaitu 12,51 N/mm². Lem anchor hasil penelitian telah memenuhi persyaratan SNI 06-6049-1999 tentang polivinil asetat emulsi untuk pengerjaan kayu sebagai standar pembanding yaitu memiliki kekuatan rekat minimal $3 \mathrm{~N} / \mathrm{mm} 2$ dan memiliki $\mathrm{pH}$ (3-8).
\end{abstract}

Keywords: Anchor, fosil, kuat tekan.

\begin{abstract}
The Conservation Office of Sangiran Early Man Site has used natural anchor materials as adhesives to connect broken fossils since 2018 after conducting research for two years, namely in 2016 and 2017. Over time, the use of natural anchor materials has been damaged, such as the result of broken or cracked joints caused by improper fossil storage. This study aims to determine the mechanical strength of a mixture of fossils and anchors. The study used a one-factor completely randomized design with variations in the ratio of 100 mesh and anchor fossils $(1: 1,2: 1$, and 3:1) with two replications. Then perform a compressive strength test using a universal testing machine based on the ASTM D695-96 standard. The compressive strength value of a mixture of natural anchor material samples with fossil powder grain size of 100 mesh is highest at a ratio of 1:1 fossil powder, which is 19,996 N/mm2 and the lowest compressive strength value at a ratio of 1:3 fossil powder, which is $12.51 \mathrm{~N} / \mathrm{mm} 2$. The research of anchor glue has met the requirements of SNI 06-6049-1999 regarding polyvinyl acetate emulsion for woodworking as a comparison standard, which has a minimum adhesive strength of 3 N/mm2 and has a pH of (3-8).
\end{abstract}

Keywords: Anchor, fossil, compressive strength

\section{PENDAHULUAN}

TEKNOSAINS: Jurnal Sains, Teknologi \& Informatika is licensed under a Creative Commons Attribution-NonCommercial 4.0 International License. 
Fosil merupakan Objek yang Diduga Cagar Budaya (ODCB) yang menurut Undang Undang Cagar Budaya Nomor 11 Tahun 2010 diperlakukan seperti Benda Cagar Budaya terutama dalam hal pelestariannya. Pemeliharaan Cagar Budaya bertujuan untuk mencegah dan menanggulangi kerusakan akibat pengaruh alam dan/atau perbuatan manusia. Pemeliharaan Cagar Budaya dilakukan dalam bentuk konservasi. Pada dasarnya terdapat dua prinsip dalam konservasi Cagar Budaya yang harus tetap dipertahankan dalam melakukan konservasi terhadap suatu Cagar Budaya. Prinsip arkeologis dan prinsip teknis. Prinsip arkeologis artinya penanganan konservasi harus memperhatikan nilai arkeologis yang terkandung di dalam benda cagar budaya, yang meliputi keaslian bahan, keaslian desain, keaslian teknologi pengerjaan dan keaslian tata letak[1]. Sedangkan prinsip teknis konservasi Cagar Budaya meliputi metode konservasi harus bersifat reversible, artinya bahan dan cara konservasi harus bisa dikoreksi sewaktu-waktu, apabila di kemudian hari ditemukan bahan dan teknologi yang lebih maju dan lebih menjamin kondisi kelestariannya. Selain itu teknik penanganan konservasi harus efektif, efisien, aman dan perlu dilakukan secara pengamatan secara berkala baik terhadap cagar budaya maupun lingkungannya untuk mengetahui kondisi cagar budaya maupun efektifitas penanganan konservasi yang telah dilakukan.

Sebelum menggunakan bahan alam, Balai Pelestarian Situs Manusia Purba Sangiran menggunakan epoksi resin sebagai lem untuk menyambungkan fosil yang patah. Perekat (lem) merupakan komponen utama untuk melakukan preparasi fosil. Perekat memberikan dukungan struktural pada spesimen fosil ketika matriks tanah di sekitarnya dihilangkan selama proses pembersihan. Namun, jika perekat lebih kuat melekat daripada struktur fosil, tekanan fisik dari perekat dapat menyebabkan patahan baru terjadi pada fosil dan memungkinkan kegagalan sambungan perekat[2]. Sedangkan dalam melakukan perbaikan fosil diupayakan menggunakan bahan yang paling sedikit yang menyebabkan kerusakan fosil. Karena itu pemilihan perekat sangat penting karena perekat yang ideal akan cukup kuat untuk mengikat namun tidak menyebabkan kegagalan sambungan karena mengakibatkan patahan pada bagian lain. Dan penting kiranya bagi konservator untuk melakukan evaluasi terhadap perekat yang sudah dipakai selama ini. Apakah menimbulkan dampak negatif pada objek baik jangka pendek maupun jangka panjang, bagaimana stabilitasnya, reversibilitasnya, apakah menimbulkan perubahan warna atau tidak, hal ini perlu dipikirkan secara bijak.

Pada tahun 2015 telah dilakukan penelitian oleh Balai Konservasi Borobudur tentang pengembangan bahan alam (anchor, gondorukem, dan gelatin) sebagai bahan perekat konservasi Cagar Budaya berbahan dasar kayu[3]. Selanjutnya pada tahun 2016 Balai Pelestarian Situs Manusia Purba Sangiran melakukan kajian penggunaan bahan perekat alternatif dari alam yang bisa digunakan untuk menyambungkan fosil yang patah. Bahan alam yang digunakan antara lain gondorukem yakni produk olahan dari pohon pinus (Pinus merkusii), damar yang merupakan salah satu jenis getah yang didapatkan dari jenis pohon damar (Agathis dammara). Damar ini ada dua jenis yaitu damar batu yaitu damar bermutu rendah berwarna coklat kehitaman, yang keluar dengan sendirinya dari pohon yang terluka. Yang kedua adalah damar mata kucing (Shorea javanica dan Hopea dryobalanoides) yaitu damar yang bening atau kekuningan yang bermutu tinggi, sebanding dengan kopal, yang dipanen dengan cara melukai kulit pohon. Kemudian bahan alam yang berasal hewani yakni lem hewani/ animal glue (anchor).

Animal glue merupakan polimer alam yang dihasilkan dari kolagen ikan atau mamalia yang merupakan struktur protein utama penyusun kulit, jaringan ikat, tulang rawan dan tulang[4]. Kolagen terdiri dari molekul protein panjang yang terdiri dari rangkaian asam amino yang memiliki ikatan kovalen yang kuat. Lem hewan mencakup berbagai perekat dari bagian tubuh hewan termasuk gelatin, di mana gelatin adalah bahan berprotein yang diperoleh secara kimia dan maupun fisik dari kolagen yang ada di tulang rawan, tendon, dan jaringan ikat. Lem tulang umumnya lebih berwarna gelap 
(kuning hingga coklat) dan kurang transparan daripada gelatin karena pengotornya yang lebih tinggi. Karakteristik lem hewan dapat dilihat dari sifat fisik dan sifat mekanik perekat seperti kekuatan gel, viskositas, kemampuan penetrasi, kecepatan distribusi dan kekuatan ikatan antar partikelnya. Meskipun berbahan dasar alam, lem hewan memiliki kekuatan yang baik, hal ini mengapa lem hewan telah digunakan sejak dahulu. hewani sudah digunakan selama ribuan tahun sebagai perekat tradisional kerajinan kayu, pembuatan kertas, penjilidan buku, industri tekstil, perekatan pita dan lainnya.

Evaluasi penggunaan bahan alam sebagai material konservasi cagar budaya harus dilakukan secara berkala. Termasuk dalam pemantauan area penyimpanan koleksi. Beberapa referensi mengatakan bahwa animal glue akan mengalami kerusakan pada kondisi lingkungan mikro koleksi yang tidak tepat. Pada kelembaban relatif $80 \%$, animal glue telah kehilangan semua kekakuannya. Pada tingkat kelembaban relatif tinggi (di atas $85 \%$ ) film lem hewan mengalami reformasi struktur heliks secara berkelanjutan dan menghasilkan tekanan yang lebih tinggi sehingga menyebabkan penyusutan parah karena kontraksi matriks lem[5].

Reversibilitas perekat juga dievaluasi sebelum dan sesudah pengaplikasian dengan penggunaan pelarut[6]. Berdasarkan teori dan praktek, air hangat dapat digunakan untuk melarutkan kembali animal glue (anchor). Hal ini membuktikan bahwa anchor merupakan bahan konservasi yang reversible terhadap objek Cagar Budaya. Menurut referensi, beberapa kelebihan anchor sebagai perekat objek cagar budaya diantaranya anchor memiliki ketahanan yang cukup tinggi setelah dilakukan ageing test dengan sinar UV yang diaplikasikan pada artefak kayu[6]

Kekuatan lem hewan bisa ditingkatkan dengan penambahan jumlah yang sesuai alkohol (etanol) dan gliserin[7]. Selain itu sebelum penyimpanan objek yang telah diaplikasikan dengan animal glue sebaiknya adalah ditambahkan agen penyamakan, seperti: aluminium trisulfat (tawas), dinatrium triborat (boraks), natrium asetat atau formaldehida, untuk meningkatkan kekerasan dan ketahanan pada lapisan film pada lem. Garam-garam ini menghilangkan sejumlah air terikat dari matriks protein dengan ikatan kovalen ke situs hidrofilik dalam lem, sehingga menginduksi pembentukan banyak ikatan silang baru antara molekul protein.

Berdasarkan hasil kajian yang telah dilakukan Balai Pelestarian Situs Manusia Purba Sangiran tahun 2016, semua bahan perekat alam yang diujicobakan bisa digunakan untuk menyambungkan fosil yang patah[8]. Namun berdasarkan data hasil pengujian karakterisasi, bahan alam jenis anchor memiliki kualitas yang lebih bagus daripada bahan alam yang lain. Determinasi kualitas perekat salah satunya dengan melihat derajat keasaman $(\mathrm{pH})$ serta kenampakan visualnya[9]. Karakterisasi perekat dilakukan dengan uji organoleptis. Data sifat fisik dan sifat kimia anchor setelah dilakukan uji organoleptis warna dan pengamatan visual diantaranya berwarna putih susu kekuningan serta bebas pengotor dan memiliki $\mathrm{pH} 7$.

Selanjutnya kajian dilanjutkan pada tahun 2017 untuk melakukan pengujian lanjutan untuk mengetahui karakterisasi bahan alam lebih lanjut. Kajian bahan konservan tahun 2017 melakukan pengujian kuat tarik material bahan perekat (anchor, damar batu, damar mata kucing dan gondorukem) dengan tensile strength. Berdasarkan hasil kajian bahan konservan tahun 2017[10], diperoleh hasil bahwa perekat alam memiliki kuat tarik paling besar adalah anchor. Berdasarkan hasil kajian bahan konservan tahap I (2016) dan kajian bahan konservan tahap II (2017), maka anchor memiliki kualitas paling unggul di antara bahan alam lainnya sehingga sampai saat ini anchor digunakan sebagai bahan alternatif untuk menyambungkan fosil di Balai Pelestarian Situs Manusia Purba Sangiran.

Seiring berjalannya waktu, bahan alam sebagai bahan konservan fosil akan mengalami kerusakan. Hal tersebut terjadi seperti pada kasus di dalam tempat penyimpanan fosil, misalnya fosil mengalami penumpukan di rak penyimpanan cenderung akan menyebabkan fosil mengalami kerusakan seperti menjadi patah, retak, ataupun hancur. Selain itu, beberapa hasil sambungan fosil dengan bahan alam 
ada yang terlepas sambungannya yang kemungkinan karena kondisi suhu dan kelembaban di dalam ruang penyimpanan yang kurang tepat.

Berdasarkan studi kasus di lapangan tersebut, maka dilakukan penelitian lanjutan tentang bahan alam anchor sebagai bahan konservasi fosil dengan melakukan pengujian kekuatan mekanik. Pengujian kekuatan mekanik pada bahan konservan sangat diperlukan untuk menentukan kekuatan mekanik dari material itu sendiri. Pengujian kekuatan mekanik material bahan alam dilakukan dengan menggunakan alat Universal Testing Machine (UTM). Diharapkan hasil penelitian ini dapat digunakan di Balai Pelestarian Situs Manusia Purba Sangiran serta ada rekomendasi yang tepat untuk tempat penyimpanan koleksi fosil.

\section{METODE}

Penelitian dilakukan di Balai Pelestarian Situs Manusia Purba Sangiran dan Laboratorium Fakultas Matematika dan Ilmu Pengetahuan Alam Terpadu Universitas Sebelas Maret Surakarta. Rancangan penelitian berupa rancangan acak lengkap satu faktor dengan dua kali pengulangan.

\subsection{Alat dan Bahan}

Pada penelitian bahan alam anchor sebagai bahan konservasi fosil digunakan alat dan bahan yaitu gelas beker $50 \mathrm{ml}$, pengaduk kaca, pemanas listrik, mortar + alu, timbangan analitik, gelas beker 100 $\mathrm{mL}$, gelas ukur $10 \mathrm{ml}$, sieve shaker ukuran 100 mesh, cetakan yang berukuran standar sesuai spesimen uji $(25,4 \times 12,7 \times 12,7) \mathrm{mm}$. Bahan yang digunakan adalah anchor, akuades, dan serbuk fosil.

\subsection{Formulasi Sampel}

Formulasi sampel bahan alam anchor dan serbuk fosil yang digunakan dalam penelitian terbagi menjadi 6 buah variasi dengan rincian terdapat dalam Tabel 1. Variasi yang digunakan adalah campuran serbuk fosil ukuran butir 100 mesh $(0,150 \mathrm{~mm})$ dengan anchor F1(1:1),F2 (2:1), dan F3 (3:1). Anchor yang digunakan adalah 5 gram dalam $10 \mathrm{~mL}$ akuades.

Tabel 1. Formulasi serbuk fosil dan anchor

\begin{tabular}{ccc}
\hline Formulasi & Serbuk fosil $(\mathrm{g})$ & Anchor $(\mathrm{g})$ \\
\hline F1 & 5 & 5 \\
F2 & 10 & 5 \\
F3 & 15 & 5 \\
\hline
\end{tabular}

\subsection{Cara Kerja}

Proses pembuatan/preparasi sampel bahan alam anchor untuk pengujian kuat material dengan Universal Testing Machine adalah memilih fosil yang fragmentaris dan tidak terpakai. Menghaluskan fosil yang telah dipilih dengan menggunakan mortar dan alu. Menyaring serbuk fosil dengan menggunakan sieve shaker menjadi ukuran butir 100 mesh $(0,150 \mathrm{~mm})$. Kemudian menimbang anchor dengan timbangan analisis sebanyak 5 gram, memanaskan air dengan kompor listrik sebanyak $10 \mathrm{~mL}$, mencampurkan bahan perekat anchor ke dalam air setelah mencapai suhu sekitar $60-70^{\circ} \mathrm{C}$ dan mengaduknya sampai homogen. Selanjutnya mencampurkan serbuk fosil hasil ayakan dengan larutan anchor masing-masing 1:1, 2:1, dan 3:1, mengaduk campuran serbuk fosil dengan anchor. Kemudian mencetak adonan kedalam cetakan yang berukuran standar sesuai spesimen uji $(25,4 \times 12,7 \times 12,7)$ mm, Menunggu cetakan menjadi agak menjadi keras, melepaskan sampel dari cetakan, mengeringkan sampel dalam suhu ruangan selama 1×24 jam. Setelah kering melakukan pengujian kuat tekan material bahan alam dengan menggunakan alat universal testing machine.

Pada penelitian ini dilakukan pengujian kuat tekan (compressive strength) bahan alam dilakukan terhadap spesimen batang uji yang standar. Pengujian kuat tekan material mengacu standart ASTM D695-96 dengan ukuran spesimen uji yaitu dengan dimensi panjang sampel 25,4 mm, lebar sampel 
$12,7 \mathrm{~mm}$, dan tebal sampel 12,7 $\mathrm{mm}[11]$. Kuat tekan beban material adalah besarnya beban per satuan luas, yang menyebabkan benda uji material hancur bila dibebani dengan gaya tekan tertentu, yang dihasilkan oleh mesin tekan. Nilai kuat tekan material dapat dihitung dengan persamaan berikut: $\mathrm{F}=$ P/A. Dimana: $\mathrm{F}=$ kuat tekan material masing-masing benda uji $\left(\mathrm{kg} / \mathrm{mm}^{2}\right), \mathrm{P}=$ beban runtuh yang diterima benda uji $(\mathrm{kg}), \mathrm{A}=$ luas bidang tekan $\left(\mathrm{mm}^{2}\right)$.

\section{HASIL DAN PEMBAHASAN}

Preparasi sampel sebelum dilakukan pengujian kuat tekan adalah dengan menghaluskan fosil menjadi serbuk dengan tujuan untuk meningkatkan homogenitas antara fosil dengan anchor sehingga memperluas ikatan antar partikel dan meningkatkan kekuatannya. Semakin kecil ukuran butir pengisi suatu komposit maka luas kontak permukaan antara butir semakin luas, dengan kata lain kekuatan suatu komposit dapat ditingkatkan dengan memperkecil ukuran butirnya[12]. Untuk membuat serbuk fosil dengan cara menghaluskan fosil-fosil yang fragmentaris dan tidak terdata atau kondisinya sudah rusak parah dan tidak dapat diperbaiki lagi sehingga aman untuk percobaan. Pada Gambar 1 menunjukkan hasil campuran fosil dengan anchor. Ukuran serbuk fosil 100 mesh ini berdasarkan ukuran butir tanah yang digunakan untuk proses kamuflase (penyelarasan warna) pada saat konservasi fosil[1]. Berdasarkan uji organoleptis tekstur dan warna campuran serbuk fosil dan anchor memiliki tekstur yang padat dan kenyal, tidak terlalu lembek dan relatif cepat kering. Campuran berwarna terang (coklat muda) sehingga tidak merubah warna fosil.

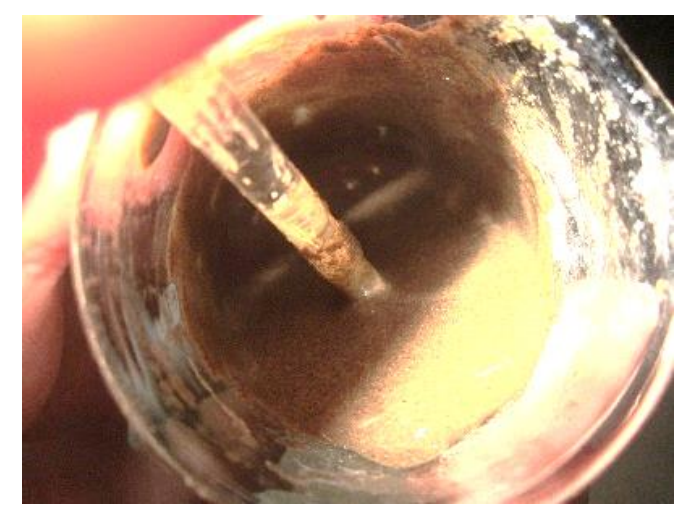

Gambar 1. Mencampur fosil dengan anchor

Setelah mencampur kedua material tersebut kemudian mempersiapkan cetakan sampel dengan ukuran sesuai syarat spesimen uji standart ASTM D695-96. Gambar 2 menunjukkan hasil cetakan fosil yang masih basah.

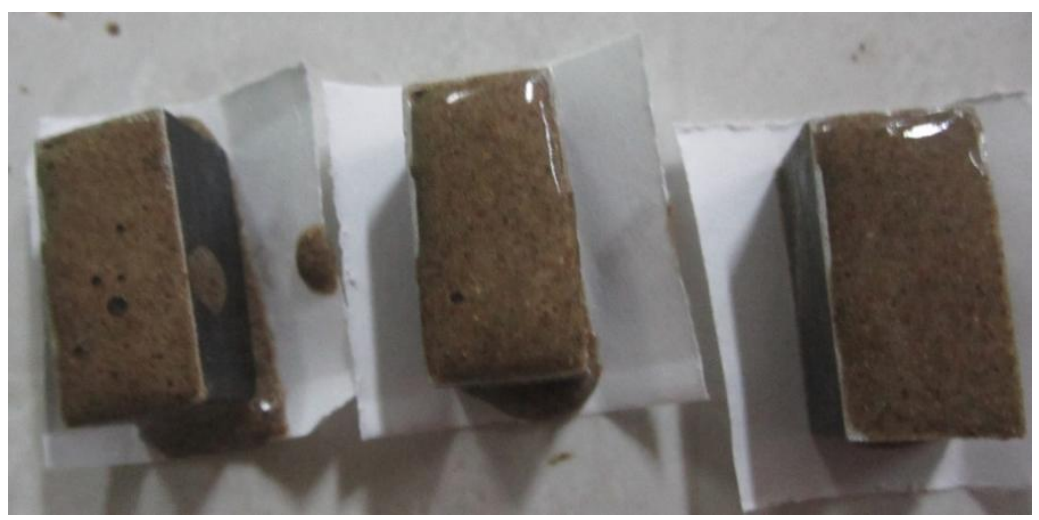

Gambar 2. Cetakan fosil masih basah 
Pembuatan perbandingan campuran serbuk fosil dengan anchor 1:1, 2:1, dan 3:1 berdasarkan penelitian yang pernah dilakukan oleh Balai Konservasi Borobudur tentang Konsolidan Fosil dengan Gelatin (2019)[13]. Hasil cetakan fosil dan anchor yang telah kering disajikan pada Gambar 3.

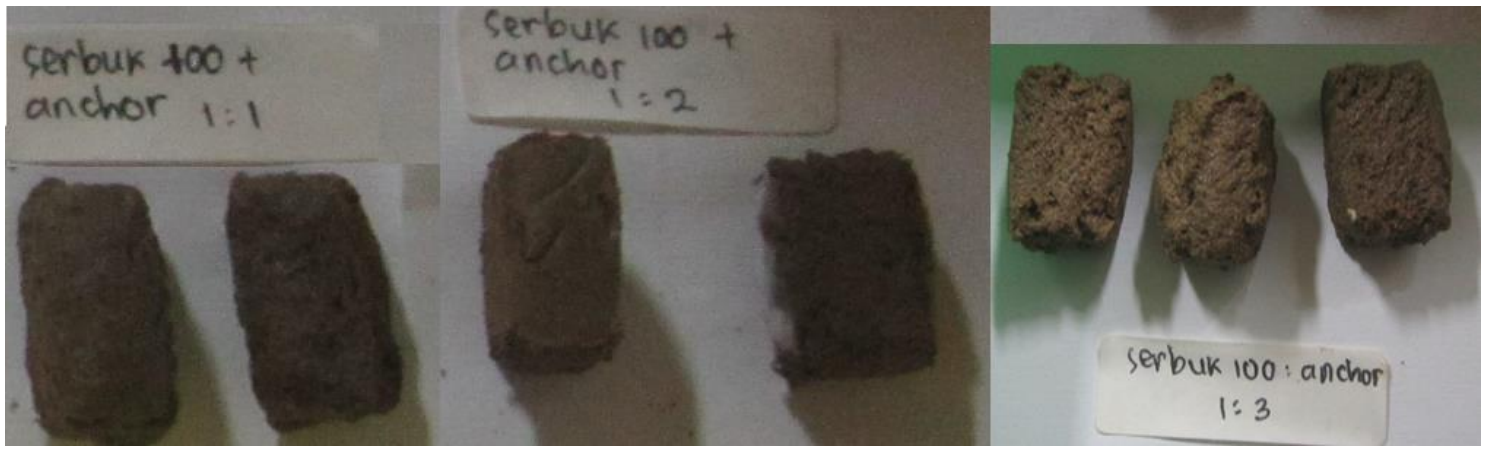

Gambar 3. Hasil cetakan fosil dan anchor yang telah kering

Pengujian kuat tekan sampel dengan menggunakan universal testing machine dilakukan di laboratorium Fakultas Matematika dan Ilmu Pengetahuan Alam Terpadu Universitas Sebelas Maret Surakarta. hasil pengujian sampel dapat dilihat pada Tabel 2.

Tabel 2. Hasil uji kuat tekan fosil dan anchor

\begin{tabular}{cc}
\hline Formulasi & Nilai Kuat Tekan $\left(\mathrm{N} / \mathrm{mm}^{2}\right)$ \\
\hline F1 & 19,996 \\
F2 & 19,787 \\
F3 & 12,510 \\
\hline
\end{tabular}

Berdasarkan Tabel 2 dapat diketahui bahwa formulasi serbuk fosil ukuran 100 mesh dengan anchor perbandingan 1:1 memiliki kuat tekan $19,996 \mathrm{~N} / \mathrm{mm}^{2}$, pada perbandingan 2:1 memiliki kuat tekan $19,787 \mathrm{~N} / \mathrm{mm}^{2}$, dan $3: 1$ memiliki kuat tekan $12,51 \mathrm{~N} / \mathrm{mm}^{2}$. Nilai kuat tekan tertinggi pada campuran serbuk fosil dan anchor 1:1 yaitu 19,996 N/mm². Sedangkan nilai kuat tekan campuran serbuk fosil dan anchor 3:1 yaitu 12,51 N/mm². Dari Tabel 2 dibuat grafik ditampilkan pada Gambar 4.

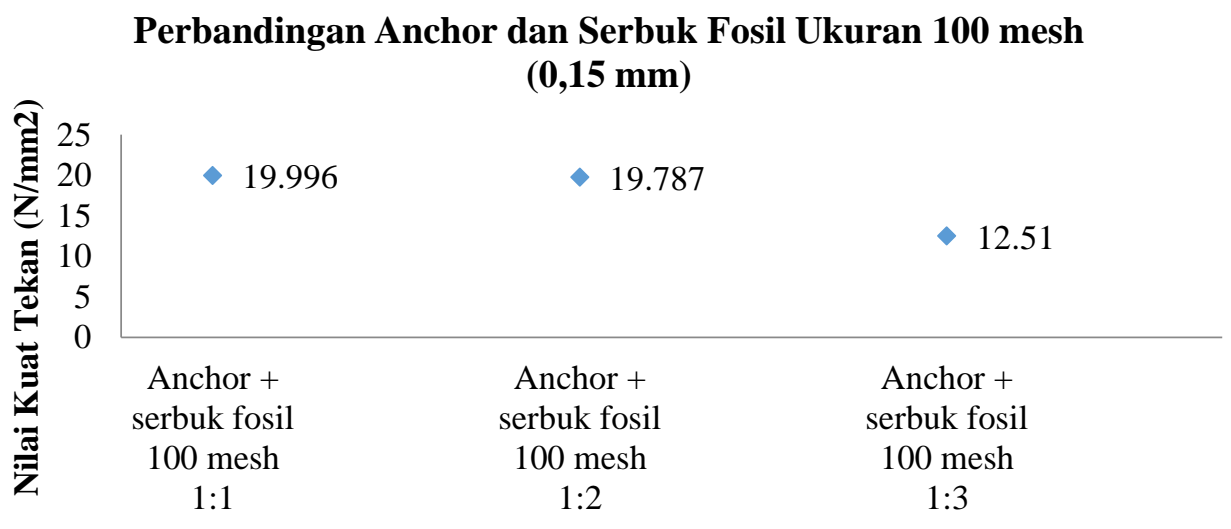

Gambar 4. Nilai kuat tekan fosil dan anchor 
Berdasarkan Gambar 4 dapat dilihat bahwa nilai kuat tekan bahan alam anchor menurun seiring dengan bertambahnya jumlah serbuk fosil. Hal ini berarti semakin banyak jumlah serbuk fosil yang ditambahkan maka kepadatan sampel akan semakin tinggi namun nilai kekuatan mekanik sampel akan semakin menurun. Nilai kuat tekan tertinggi pada perbandingan serbuk fosil dan anchor 1:1 yaitu $19,996 \mathrm{~N} / \mathrm{mm}^{2}$ dan memiliki nilai kuat tekan terendah pada perbandingan serbuk fosil dan anchor 3:1 yaitu $12,51 \mathrm{~N} / \mathrm{mm}^{2}$. Nilai keteguhan rekat pada lem kolagen ikan Tongkol adalah 7,7 N/mm2[14], sedangkan nilai keteguhan rekat lem ikan Cobia yaitu sebesar 5,3 N/mm2. Jadi anchor memiliki nilai kekuatan mekanik yang lebih tinggi daripada lem ikan.

Perbandingan jumlah serbuk fosil yang ditambahkan pada suatu perekat mempengaruhi kekuatan perekat, hal ini nampak seperti data yang disajikan pada Tabel 2. Suatu lem/ perekat yang baik adalah lem yang berbentuk tidak terlalu encer ataupun tidak terlalu kental[14]. Hal tersebut dikarenakan lem yang memiliki viskositas yang sesuai akan mampu menembus pori fosil dengan baik dan selanjutnya membentuk ikatan yang optimum sehingga menghasilkan daya rekat yang optimal. Berdasarkan data Tabel 2 perbandingan serbuk fosil dan anchor optimum adalah 1:1.

Nilai kuat tekan sampel bergantung pada saat preparasi sampel baik pada saat pencampuran bahan alam anchor dengan serbuk fosil, pengadukan, pencetakan hingga pengeringan sampel sebelum dilakukan pengujian kuat tekan dengan Universal Testing Machine. Beberapa faktor yang mempengaruhi nilai kekuatan suatu perekat di antaranya adalah komposisi dari lem itu sendiri, jumlah lem yang diberikan pada permukaan bahan serta kehalusan dan kekasaran permukaan benda yang akan direkatkan[15]. Sedangkan kekuatan perekat dipengaruhi oleh kondisi dari perekatan yang meliputi durasi perekatan dan cara perekatan suatu benda.

Berdasarkan data yang diperoleh dari penelitian yang dilakukan oleh Balai Pelestarian Situs manusia Purba Sangiran makan bahan alam anchor telah memenuhi salah satu persyaratan SNI 066049-1999 polivinil asetat emulsi untuk pengerjaan kayu sebagai standar pembanding yaitu memiliki pH antara 3-8 (anchor memiliki pH 7). Selanjutnya berdasarkan hasil penelitian ini bahan alam anchor juga telah memenuhi salah satu persyaratan SNI 06-6049-1999 polivinil asetat emulsi untuk pengerjaan kayu sebagai standar pembanding yaitu memiliki kekuatan rekat minimal $3 \mathrm{~N} / \mathrm{mm}^{2}$. Jadi campuran serbuk fosil dengan anchor perbandingan 1:1, 2:1, dan 3;1 dapat digunakan sebagai bahan perekat karena telah memenuhi persyaratan SNI .

\section{SIMPULAN}

Sebagai polimer alami, kinerja animal glue (anchor) adalah sebagian tergantung pada sumber kolagen asli, yang menentukan komposisi kimia lem, tetapi juga sangat dipengaruhi oleh ekstraksi dan preparasi. Berdasarkan hasil penelitian pemanfaatan bahan alam anchor sebagai bahan konservasi fosil di Sangiran maka dapat ditarik beberapa kesimpulan yaitu: 1) Lem anchor hasil penelitian telah memenuhi persyaratan SNI 06-6049-1999 tentang polivinil asetat emulsi untuk pengerjaan kayu sebagai standar pembanding yaitu memiliki kekuatan rekat minimal $3 \mathrm{~N} / \mathrm{mm}^{2}$ dan memiliki $\mathrm{pH}(3-8)$. 2) Nilai kuat tekan campuran sampel bahan alam anchor dengan serbuk fosil ukuran butir 100 mesh tertinggi pada perbandingan serbuk fosil dan anchor 1:1 yaitu 19,996 N/mm² dan memiliki nilai kuat tekan terendah pada perbandingan serbuk fosil dan anchor $3: 1$ yaitu $12,51 \mathrm{~N} / \mathrm{mm}^{2}$. 3) Nilai kuat tekan serbuk fosil dan anchor bergantung pada saat preparasi sampel baik pada saat pencampuran bahan alam anchor dengan serbuk fosil, pengadukan, pencetakan sampel hingga pengeringan sampel sebelum dilakukan pengujian kuat tekan dengan universal testing machine.

\section{UCAPAN TERIMA KASIH}

Ucapan terima kasih kami ucapkan kepada Universitas Muhammadiyah Surakarta yang telah mensponsori untuk pelaksanaan University Research Colloquium (URECOL) ke-14. 
Pemanfaatan Bahan Alam Anchor sebagai Bahan Konservasi Fosil di Sangiran

\section{REFERENSI}

[1] Anonim. "Standart Operating Procedure”. Balai Pelestarian Situs Manusia Purba Sangiran. Kementerian Pendidikan dan Kebudayaan, Direktorat Jenderal Kebudayaan. 2015.

[2] R. R. and S. B, "Keep It Together: An Evaluation Of The Tensile Strengths Of Three Select Adhesives Used In Fossil Preparation," Collect. Forum 2016; 30(1)85-95. Soc. Preserv. Nat. Hist. Collect.

[3] Y. Haldoko, L. A., Kasatriyanto, B., Suryanto, R.K., Yulianto, H., and Setyoharjono, Laporan Hasil Kajian Pengembangan Perekat Alam Untuk Penyambungan Artefak Kayu. Balai Konservasi Borobudur. Kementerian Pendidikan dan Kebudayaan, Direktorat Jenderal Kebudayaan, 2015.

[4] S. N, "Animal Glues - their adhesive properties, longevity and suggested use for repairing," Nat. Sci. Collect. Assoc. News, vol. 36-40, no. 16, 2009.

[5] B. A. et Al, "Mechanical properties of mammalian and fish glues over range of temperature and humidity," J. Cult. Herit. 53 226-235. Publ. by Elsevier Masson SAS, 2021.

[6] E. a. Tsetsekou, E., "Assessing wood adhesives used in conservation by testing their bond strength," 1st Int. Conf. Greek Soc. Exp. Mech. Mater. El Sevier Ltd, 2018.

[7] S. N, "Animal glues: a review of their key properties relevant to conservation," Rev. Conserv. Number 8 June 2007, Artic. Stud. Conserv., 2007.

[8] Anonim. "Laporan Kajian Bahan Konservan Fosil Tahap I (Bahan Perekat)". Balai Pelestarian Situs Manusia Purba Sangiran. Kementerian Pendidikan dan Kebudayaan, Direktorat Jenderal Kebudayaan, 2016.

[9] T. Sucipto, "Determinasi Kualitas Perekat. Karya Tulis". Depatemen Kehutanan, Fakultas Pertanian, Universitas Sumatera Utara," 2009.

[10] Anonim. "Laporan Kajian Bahan Konservan Fosil Tahap II (Bahan Perekat)." Balai Pelestarian Situs Manusia Purba Sangiran. Kementerian Pendidikan dan Kebudayaan, Direktorat Jenderal Kebudayaan, 2017.

[11] H. Harsi, N. H. Sari, and S. Sinarep, "Karakteristik Kekuatan Bending Dan Kekuatan Tekan Komposit Serat Hybrid Kapas/Gelas Sebagai Pengganti Produk Kayu," Din. Tek. Mesin, vol. 5, no. 2, pp. 59-65, 2015, doi: 10.29303/d.v5i2.30.

[12] D. Setiawan A, "Pengaruh Ukuran Butir Serbuk Fly Ash Terhadap Kekuatan Impact Bahan Komposit Bermatriks Epoxy," J. Fema, vol. 1, no. 4, 2013.

[13] Anonim. "Laporan Kajian Konsolidasi Fosil." Balai Konservasi Borobudur. Kementerian Pendidikan dan Kebudayaan, 2019.

[14] E. Sulistyanto, Y. Darmanto, and U. Amalia, "Karakteristik lem ikan dari tiga jenis ikan laut yang berbeda," J. Ilmu dan Teknol. Kelaut., vol. 7, no. 1, pp. 23-32, 2015.

[15] N. . Eskani, I.N., Widiastuti, R. and Lathifah, "'Karakterisasi Perekat Alami Dari Tumbuhan Untuk Industri Kerajinan”," 2017. 